\title{
Schistosomiasis, hepatitis B and hepatitis C co-infection
}

\author{
Gasim I Gasim', Abdelhaleem Bella ${ }^{2}$ and Ishag Adam ${ }^{1,3^{*}}$
}

\begin{abstract}
Background: Schistosomiasis is a significant health problem in more than 70 countries distributed between Africa, Asia and South America, with an infection rate of one in 30 individuals. Data on Schistosomiasis, Hepatitis B virus (HBV) and Hepatitis C virus (HCV) co-infection are scarce; however, there is a high prevalence in countries where schistosomiasis is endemic.

Methods: A systematic search was performed on published data from 1980-2014. Published papers in the databases Google, Medline, PubMed, and MiPc library were searched using the keywords epidemiology, pathogenesis and outcomes of HBV, HCV and schistosomiasis and data were extracted from the relevant studies.

Results: The prevalence of HBV/schistosomiasis co-infection in countries where schistosomiasis is endemic was high, ranging between 9.6 to approximately 64\% in Egypt, and a maximum of 15.8\% among hospitalized patients in Brazil. Concurrent infection between HBV and schistosomiasis is often associated with countries where schistosomiasis is endemic and may lead to chronic liver inflammation. Similarly, HCV infection rates in schistosomiasis populations range from $1 \%$ in Ethiopia reaching up to $50 \%$ in Egypt.
\end{abstract}

Conclusion: There is controversy regarding the effects of HBV and HCV on schistosomiasis and vice versa. Vaccination might be a solution to the era of schistosomiasis and co-infection with HBV and HCV.

Keywords: Schistosomiasis, HBV, HCV, Hepatotropic, Vaccine, Adjuvant

\section{Introduction}

Schistosomiasis is a parasitic infection that is second to malaria in prevalence and affects about 200 million people in over 70 countries with an infection rate of one in 30 individuals [1,2]. It is of particular importance in Africa and South America owing to its endemicity, high prevalence and morbidity rates in countries such as Nigeria, Tanzania, Democratic Republic of Congo, Ghana, and Brazil $[1,3]$. The prevalence of schistosomiasis was estimated to range between 3 to 10\% in Egypt while in Tanzania it ranges from $2.7 \%$ to $35.6 \%[4,5]$. Schistosomiasis is a complex tropical disease caused by Schistosoma species, of which Schistosoma haematobium, S. mansoni, and S. japonicum are the most common [6]. The diverse clinical patterns of this infection depend on the interplay of numerous factors, such as parasite strain, host genetic background, host immunity

\footnotetext{
* Correspondence: ishagadam@hotmail.com

${ }^{1}$ Qassim College of Medicine, Qassim University, Buraydah, Saudi Arabia

${ }^{3}$ Faculty of Medicine, University of Khartoum, P.O. Box 102, Khartoum, Sudan Full list of author information is available at the end of the article
}

and nutritional status, and co-infections [7-11]. Often, disease progresses to an advanced stage, called hepatosplenic schistosomiasis (HSS), which is frequently seen in endemic areas and is characterized by portal hypertension that may lead to gastrointestinal bleeding $[12,13]$.

Concurrent infection between hepatitis B virus (HBV) and schistosomiasis is often observed in countries where schistosomiasis is endemic and might cause chronic liver inflammation [14]. S. mansoni and HBV co-infection pathogenesis remains controversial; however, the harmful effects of $S$. mansoni and hepatitis $\mathrm{C}$ virus (HCV) coinfection on liver fibrosis have demonstrated in endemic countries [15-17]. Chronic HCV infection is a prevalent chronic liver disease globally, with a burden approaching of 185 million people testing positive for $\mathrm{HCV}$ antibodies (2.8\% prevalence) with the highest prevalence in North and East Asia, the Middle East and North Africa region ( $>3.5 \%$ prevalence) [18]. The three infections (schistosomiasis, HBV, HCV) induce acute and chronic manifestations that mainly affect the liver with variable degrees 
and patterns of liver dysfunction. Therefore, co-infection may have an impact on disease pathophysiology which is assessed in this article. Treatment of any of the three conditions might impact on the other infection. For example, in Egypt, the use of unsterile syringes during mass campaigns of intravenous anti-schistosomiasis treatment was suggested to be the main reason for the spread of HCV [19]. This review was conducted to address the gap of knowledge regarding the above mentioned co-infections.

\section{Review}

A systematic search of published data during the period 1980-2014was performed. Published papers on epidemiology pathogenesis and outcomes of HBV and schistosomiasis were extracted from relevant studies provided they are written in English or at least their abstracts are in English. Databases were searched using different search engines including Medline, PubMed, MiPc library and Google with the keywords "Hepatitis B virus", "schistosomiasis", "epidemiology", "Africa" and "South America" and names of particular countries where they were entered interchangeably. We excluded articles using serological methods to diagnose schistosomiasis.

\section{Epidemiology of co-infection with schistosomiasis, HBV and HCV}

Published data on HBV and schistosomiasis co-infection is scarce where we found about 15 articles fulfilling our criteria; however, in countries where schistosomiasis is endemic such as Egypt, a high prevalence of HBV and $S$. mansoni co-infection has been described ranging from 19.6 to $33.0 \%[20,21]$. The prevalence of co-infection among the general population in Brazil is $15.8 \%$ [22]. A high $(58.4 \%)$ prevalence of HBV was reported among Chinese patients with chronic schistosomiasis [23].

Similarly, published data about HCV and schistosomiasis co infection is scanty where only 16 articles could fulfill our criteria. Prevalence rates of $\mathrm{HCV}$ infection with wide variations as low as $1 \%$ and as high as $50 \%$ among patients with schistosomiasis, were reported in different countries [24-26]. Likewise high (40.2\%) prevalence of HCV and S. mansoni antibodies were detected among 233 wastewater treatment plants workers [27]. Interestingly, a more recent study among 3,596 Egyptian patients found that $27.3 \%$ had both HCV-RNA and schistosomiasis, though a weak point is their reliance on serology to diagnose schistosomiasis, a thing that questions the association between $\mathrm{HCV}$ and schsitosomiasis [28]. Nonetheless, in Yemen a group of researchers reported a relationship between $S$. haematobium and hepatitis B, but no correlation between $S$. mansoni infection and HBV or HCV [29]. The prevalence of S. mansoni infection was $65.9 \%$ in a community-based study in
Ethiopia including 2,451 subjects. Moreover, the prevalence of schistosomal periportal thickening/fibrosis (PPT/F) was $4.6 \%$. At least one marker of either HBV or $\mathrm{HCV}$ was detected in $43.2 \%$ of the subjects, of which $5.3 \%$ were $\mathrm{HBsAg}$ positive, and $1.3 \%$ were anti-HCV [30] positive see Table 1 . PPT/F increased significantly and proportionally in terms of prevalence with community prevalence and intensity of $S$. mansoni infection [30]. It is understandable that HSS renders patients at risk of getting $\mathrm{HCV}$ owing to the involvement with the risk factors for both HBV and HCV such as history of treatment with parenteral treatment for schistosomiasis unsterile syringes during mass campaigns, blood transfusion, surgical and endoscopic interventions [21,31-35].

\section{Immunology of schistosomiasis and hepatitis B or C co-infection}

Wahib et al., demonstrated the co-infection of HBV and/or HCV in 120 patients with hepatosplenic schistosomiasis was associated with a marked depression in cell mediated immune responses [36]. Furthermore, Edwards et al., described the effects of hepatotropic virus coinfection during the Th2-dominated granulomatous phase of Schistosomal infection. They used lymphocytic choriomeningitis virus (LCMV) as a model for hepatotropic viruses, and demonstrated the induction of a strong LCMV-specific T cell response, with infiltration of large numbers of LCMV-specific interferon (IFN) $-\gamma$ producing $\mathrm{CD} 8+$ cells into the liver. This can lead to the down regulation of Th2 cytokine production that is dominant during S. mansoni infection and expeditious hepatotoxicity related morbidity. Moreover, livers of coinfected mice were highly susceptible to viral replication, which correlated with a reduction in intrahepatic type I IFN responses following virus infection [36-38].

$\mathrm{HCV}$ infection worsens the outcome of concomitant schistosomiasis and $\mathrm{HCV}$ infection, causing advanced liver disease, higher HCV RNA titers, an increase in histological activity index, increased incidence of liver cirrhosis and hepatocellular carcinoma, and increased mortality rate $[17,39]$. S. mansoni co-infection targets a specific subset of memory CD8+ T cells during HCV infection [40]. The immune response in $S$. mansoni patients with or without $\mathrm{HCV}$ infection was evaluated by assaying the serum levels of IFN- $\gamma$ and IL-5 to estimate cell mediated immunity and IgE levels to estimate humoral immunity. A shift to T helper (Th)-0 and Th-2 immunity as well as an associated reduction of Th-1 responses( more or less a shift from cellular to humoral immunity) were observed, which might have a role in the persistence and severity of both diseases. Such immunity defects can lead to less HCV clearance [41,42]. $S$. haematobium soluble egg antigen (SEA) affects the intracellular HCV RNA burden in peripheral mononuclear 
Table 1 Showing the prevalence of co-infection HCV/ HBV and hepatosplenic schistosomiasis (HSS)

\begin{tabular}{|c|c|c|c|c|}
\hline Country & $\begin{array}{l}\text { Prevalence } \\
\text { of HCV/HSS }\end{array}$ & Remarks about the study & $\begin{array}{l}\text { Prevalence } \\
\text { of HBV/HSS }\end{array}$ & Remarks about the study \\
\hline \multirow[t]{3}{*}{ Egypt } & \multirow[t]{2}{*}{$33 \%[21]$} & \multirow{2}{*}{$\begin{array}{l}\text { 1-Angelico et al [21] a small scale study } \\
\text { carried among } 135 \text { liver disease patients }\end{array}$} & \multirow[t]{3}{*}{$19.6 \%[20]-33 \%[21]$} & 1-El-Sayed et al [20] \\
\hline & & & & This is a community based study \\
\hline & $40.2 \%[27]$ & $\begin{array}{l}\text { 2- el-Esnawy [27] et al. carried a study } \\
\text { among } 233 \text { waste water treatment workers }\end{array}$ & & $\begin{array}{l}\text { 2-Angelico et al [21] a small scale study } \\
\text { carried among } 135 \text { liver disease patients }\end{array}$ \\
\hline Sudan & $2.3 \%$ & $\begin{array}{l}\text { Mudawi et al. [25] studied } 176 \text { schistosomiasis } \\
\text { patients }\end{array}$ & & \\
\hline Ethiopia & $4 \%$ & $\begin{array}{l}\text { Berhe et al. [30] studied } 199 \text { schistosomiasis } \\
\text { patients }\end{array}$ & $16.1 \%$ & $\begin{array}{l}\text { Berhe et al. [30] studied } 199 \text { schistosomiasis } \\
\text { patients }\end{array}$ \\
\hline Brazil & $12.9 \%$ & Aquino et al [22] studied 101 patients with HSS & $15.8 \%$ & Aquino et al [22] studied 101 patients with HSS \\
\hline China & $0.06 \%$ & Li et al. [26] studied 102 patients with schistosomiasis & $58.4 \%$ & Du et al. [23] studied 250 schistosomiasis patients \\
\hline
\end{tabular}

cells (PBMC) as well as cell proliferation in patients with chronic HCV infection, which is linked, in part, to the direct triggering of viral replication by SEA [43]. Lymphotoxin (LT)- $\alpha$ contributes to inflammatory responses and single-nucleotide polymorphisms (SNP) in the human LT$\alpha$ gene might have significant effects on individual susceptibility to disease. Individuals with $\mathrm{HCV}$ infection alone and those co-infected with schistosoma and HCV (but not those infected with Schistosoma alone) were significantly more likely to carry the $\mathrm{LN}-\alpha$ gene mutation than the control subjects [44]. The common IL-10 (-1082, -819 and -592) genotypes/haplotypes were not associated with susceptibility to HCV infection either alone or during coinfection with S. mansoni [45].

\section{Impact of co-infection with schistosomiasis and HBV on the individual disease course}

Chronic infections with hepatotropic viruses, such as HBV, can lead to liver cirrhosis, and an expected synergistic effect might exacerbate hepatic pathology during concomitant infections of $\mathrm{HBV}$ and schistosomiasis. Epidemiological studies were performed to investigate schistosomiasis/HBV co-infections, as no suitable animal models exist. A number of studies proposed an increased susceptibility to HBV caused by schistosomal infections (especially the severe hepatosplenic form) $[46,47]$. However, this could be explained by the frequent need of schistosomiasis patients for blood transfusion, especially on considering the poor infection control measures in countries where this disease is endemic. In contrast, other studies rejected the thesis stating any relationship between schistosomiasis and $\operatorname{HBV}[48,49]$. Woodchucks are susceptible to infection with both schistosoma and woodchuck hepatitis virus (WHV) [50]. Because HBV and WHV descend from the same family (family Hepadnaviridae), a concomitant infection of schistosomes and WHV in woodchucks might be a suitable animal model for concomitant infection in humans. However, there was no impact of schistosome infection on WHV serum markers [51]. HBV replication was inhibited in transgenic mice [52] during schistosomal infection, where the antiviral effects of schistosomes related to IFN- $\gamma$ and nitric oxide. Thus, most published studies have found no association between schistosomiasis and worsening of HBV infection [53]. In contrast, other studies described a poor prognosis of HBV when associated with hepatosplenic schistosomiasis [17,24,54]. Interestingly $\mathrm{HBV}$ vaccines (both 1st and 2nd generation) can mount an immune response in schistosomiasis patients; however, reduced responses to vaccination were seen in hepatosplenic schistosomiasis [37,55,56]. Therefore, further studies are needed to determine conclusions regarding co-infection schistosomiasis and HBV.

\section{Impact of co-infection with schistosomiasis and HCV on the individual disease course}

S. mansoni infection increases $\mathrm{HCV}$ morbidity and chronicity, which might be referred to antecedent liver decompensation $[42,57,58]$. Increased HCV RNA titers, histological activity, incidence of cirrhosis/hepatocellular carcinoma, and higher mortality rates were noticed in patients with co-infection [17]. However, a sample size of 17 patients in the previous study is not big enough to draw solid conclusions. Other studies reports found no evidence that schistosomiasis affected the outcome of $\mathrm{HCV}$ infected patients [53,59].

\section{Impact of anti-schistosomal and anti-viral therapy on co-infection}

Praziquantel is a first line therapy for the management and mass chemotherapy of schistosomiasis, and significantly reduced S. mekongi infection (from 50\% to 3\%) and the associated severe liver disease [60]. Because it is administered orally, praziquantel avoids the use of needles and therefore lowers the risk of $\mathrm{HBV}$ and $\mathrm{HCV}$ transmission in low-income countries. In a mouse model, praziquantel improved the immunogenicity of HBV vaccine [38]. Certain therapies used for the 
treatment of HBV infection have a positive effect on schistosomiasis co-infection [61]. In sixty-seven patients with advanced schistosomiasis and HBV co-infection, the use of Entecavir for 52 weeks improved liver fibrosis markers and the Ishak fibrosis score [61]. In a mouse model of infection with schistosomiasis, the use of pegylated IFN (Peg-IFN)-a drug used in treatment of HCVsignificantly reduced the worm load in mice [62]. The use of Peg-IFN could be considered for use in humans to assist patients in whom the currently used oral therapy has failed.

Another important issue in this context is the effect of schistosomiasis-HCV co-infection on the response to $\mathrm{HCV}$ treatment where some investigators have proposed that co-infection retards response to this treatment [28]. However, Derbala et al. provided a rather more solid evidence in their clinical trial that co-infection does not affect the response to such therapy [63]. Measures to reduce the transmission of HBV and HCV by attention to hygiene and strict hygienic practices, vaccination, early detection in high-risk populations and treatment will be valuable in reducing the morbidity and mortality associated with schistosomiasis co-infection.

\section{Future prospects}

As elimination of schistosomiasis is a global target, there is a need for supplementary tools, such as vaccination, to confer long-term prevention. Different approaches for vaccination development have been tested in animal models with variable immunogenicity including Biomphalaria alexandrina snail nucleoproteins, thyroid hormone receptors and more recently, the use of DNA-Smp80, and DNA-Sm14 [64-68]. The development of these vaccines relayed mainly on using a subunit approach where the minimal microbial constituents necessary to surmount an appropriate immune response are incorporated into the vaccine, these constituents were tegument proteins most of the times; nevertheless, despite the potential advantages of subunit vaccines, this method resulted in poorly immunogenic vaccines, a thing that entailed the co-administration with potent adjuvants, and in some cases, the addition of $\mathrm{T}$ helper epitopes to evoke a long lasting immune response[69].

Current approaches for $\mathrm{HCV}$ vaccine comprise a number of approaches of which are the adoption of recombinant E1 and E2 proteins, manufactured peptides, viral particles, viral vehicles, DNA vaccines, dendritic cells, and prime-boost strategies. Nevertheless, there are a number of problems including restricted humoral and cell mediated responses, low transmission of likely protective viral epitopes, and low efficiency of the adjuvants used in different protocols [70]. However, a greater understanding of co-infection and human trials are required to determine the mechanisms of vaccine-induced immunity, to establish a rational ground for novel vaccines and their optimal design. As a number of combined vaccines including $\mathrm{HBV}$ vaccine have been proven efficacious [71,72], a combination of HBV and a future schistosomiasis vaccine might also prove beneficial.

\section{Conclusion}

There are few published data on schistosomiasis, HCV and HBV co-infection. Previous studies reported a high prevalence of $\mathrm{HCV}$ and $\mathrm{HBV}$ co-infection in countries where schistosomiasis is endemic. The effect of HBV and $\mathrm{HCV}$ on schistosomiasis and vice versa remains to be a matter of debate. Vaccination is the most likely method for prevention of schistosomiasis and preventing its synergistic interactions by co-infection with $\mathrm{HBV}$ or $\mathrm{HCV}$.

\section{Competing interests}

The authors declare that they have no competing issues of interests.

\section{Authors' contributions}

GIG and IA coordinated the work and provided the required search. GIG and $A B$ reviewed the data and literature. All authors shared in drafting the paper and all approved the final version.

\section{Author details}

${ }^{1}$ Qassim College of Medicine, Qassim University, Buraydah, Saudi Arabia. ${ }^{2}$ King Fahad Hospital of the University, University of Dammam, Dammam, Saudi Arabia. ${ }^{3}$ Faculty of Medicine, University of Khartoum, P.O. Box 102, Khartoum, Sudan.

Received: 19 October 2014 Accepted: 29 January 2015 Published online: 08 February 2015

\section{References}

1. WHO: Status of Schistosomiasis endemic countries. Geneva: World Health Organization; 2012. apps.who.int/neglected_diseases/ntddata/sch/sch.html.

2. Schistosomiasis Control Program: The Carter Center http://www. cartercenter.org/resources/pdfs/factsheets/schistosomiasis-facts.pdf>. Accessed 2011 Nov 15.

3. Steinmann P, Keiser J, Bos R, Tanner M, Utzinger J. Schistosomiasis and water resources development: systematic review, meta-analysis, and estimates of people at risk. Lancet Infect Dis. 2006;6:411-25.

4. Barakat RM. Epidemiology of Schistosomiasis in Egypt: travel through time: review. J Adv Res. 2013;4:425-32.

5. Knopp S, Person B, Ame SM, Mohammed KA, Ali SM, Khamis IS, et al. Elimination of schistosomiasis transmission in Zanzibar: baseline findings before the onset of a randomized intervention trial. PLoS Negl Trop Dis. 2013;7:e2474.

6. Schmitt, I: Schistosomiasis-The burden of disease and trends of intervention. International Health Practice; April 2006. http://www.case.edu/ med/epidbio/mphp439/Schistosomiasis.htm.

7. Blanton RE, Salam EA, Kariuki HC, Magak P, Silva LK, Muchiri EM, et al. Population-based differences in Schistosomiasis mansoni and hepatitis C induced disease. J Infect Dis. 1859;2002:1644-9.

8. Boisier P, Ramarokoto CE, Ravoniarimbinina P, Rabarijaona L, Ravaoalimalala VE. Geographic diffrerences in hepatosplenic complications of Schistosomiasis mansoni and explanatory factors of morbidity. Trop Med Int Health. 2001;6:699-706.

9. Dessein AJ, Hillaire D, Elwali NE, Marquet S, Mohamed-Ali Q, Mirghani A, et al. Severe hepatic fibrosis in Schistosoma mansoni infection is controlled by a major locus that is closely linked to the interferon-gamma receptor gene. Am J Hum Genet. 1999;65:709-21.

10. King CH, Magak P, Abdel-Salam E, Ouma JH, Kariuki HC, Blanton E. Measuring morbidity in Schistosomiasis mansoni: relationship between image pattern, portal vein diameter and portal branch thickness in large-scale surveys using new WHO coding guidelines for ultrasound in schistosomiais. Trop Med Int Health. 2003;8:109-17. 
11. Mohamed-Ali Q, Elwali NE, Abdelhameed AA, Mergani A, Rahoud S, Elagib KE, et al. Susceptibility to periportal (Symmers) fibrosis in human Schistosoma mansoni infections: evidence that intensity and duration of infection, gender and inherited factors are critical in disease progression. J Infect Dis. 1999;180:1298-306.

12. Elbaz T, Esmat G. Hepatic and Intestinal Schistosomiasis: Review. JAR. 2013:4:445-52.

13. Pereira LM, Domingues AL, Spinelli V, McFarlane IG. Ultrasonography of the liver and spleen in Brazilian patients with hepatosplenic Schistosomiasis and cirrhosis. Trans R Soc Trop Med Hyg. 1998;92:639-42.

14. Conceic,ão MJ, Argento CA, Chagas VL, Takiya CM, Moura DC, Silva SC. Prognosis of Schistosomiasis mansoni patients infected with hepatitis B virus. Mem Inst Oswaldo Cruz. 1998;93:255-8.

15. El-Masry S, Lotfy M, El-Shahat M, Badra G. Serum laminin assayed by SlotBlot-ELISA in patients with combined viral hepatitis $C$ and schistosomiasis. Clin Biochem. 2006:39:652-7.

16. Kamal SM, Turner B, He Q, Rasenack J, Bianchi L, Al Tawil A, et al. Progression of fibrosis in hepatitis $C$ with and without schistosomiasis: correlation with serum markers of fibrosis. Hepatology. 2006;43:771-9.

17. Kamal SM, Rasenack JW, Bianchi L, Al Tawil A, El Sayed KK, Peter T, et al. Acute hepatitis $C$ without and with Schistosomiasis: correlation with hepatitis C-specific CD4(+) T-cell and cytokine response. Gastroenterology. 2001;121:646-56.

18. Mohd Hanafiah K, Groeger J, Flaxman AD, Wiersma ST. Global epidemiology of hepatitis C virus infection: new estimates of age-specific antibody to HCV seroprevalence. Hepatology. 2013;57:1333-42.

19. Barnard H. Hepatitis C in Egypt, a iatrogenic epidemy. Ned Tijdschr Geneeskd. 2000;144:2024-5.

20. El-Sayed HF, Abaza SM, Mehanna S, Winch PJ. The prevalence of hepatitis B and $C$ infections among immigrants to a newly reclaimed area endemic for Schistosoma mansoni in Sinai, Egypt. Acta Trop. 1997;68:229-37.

21. Angelico M, Renganathan E, Gandin C, Fathy M, Profili MC, Refai W, et al. Chronic liver disease in the Alexandria governorate, Egypt: contribution of schistosomiasis and hepatitis virus infections. J Hepatol. 1997;26:236-43.

22. Aquino RT, Chieffi PP, Catunda SM, Araújo MF, Ribeiro MC, Taddeo EF, et al. Hepatitis $B$ and $C$ virus markers among patients with hepatosplenic mansonic schistosomiasis. Rev Inst Med Trop Sao Paulo. 2000;42:313-20.

23. Du H. Relationship between advanced schistosomiasis and HBV infection. Zhongguo Xue Xi Chong Bing Fang Zhi Za Zhi. 2013;25:115-7.

24. Van-Lume DS, Albuquerque Mde F, Souza Al, Domingues AL, Lopes EP, Morais CN, et al. Association between Schistosomiasis mansoni and hepatitis C: systematic review. Rev Saude Publica. 2013;47:414-24.

25. Mudawi HM, Smith HM, Fletcher IA, Fedail SS. Prevalence and common genotypes of HCV infection in Sudanese patients with hepatosplenic schistosomiasis. J Med Virol. 2007;79:1322-4

26. Li Y, Chen D, Ross AG, Burke ML, Yu X, Li RS, et al. Severe hepatosplenic schistosomiasis: clinicopathologic study of 102 cases undergoing splenectomy. Hum Pathol. 2011:42:111-9.

27. El-Esnawy NA, Al-Herrawy AZ. Seroprevalence of certain hepatitis viruses among Egyptian workers infected with schistosomiasis. J Egypt Public Health Assoc. 2000;75:357-66.

28. Abdel-Rahman M, El-Sayed M, El Raziky M, Elsharkawy A, El-Akel W, Ghoneim H, et al. Co infection with hepatitis C virus and schistosomiasis: fibrosis and treatment response. World J Gastroenterol. 2013;19:2691-6.

29. Al-Shamiri AH, Al-Taj MA, Ahmed AS. Prevalence and co-infections of Schistosomiasis/hepatitis B and C viruses among school children in an endemic area in Taiz, Yemen. Asian Pac J Trop Med. 2011:4:404-8.

30. Berhe N, Myrvang B, Gundersen SG. Intensity of Schistosoma mansoni, hepatitis B, age, and sex predict levels of hepatic periportal thickening/ fibrosis (PPT/F): a large-scale community-based study in Ethiopia. Am J Trop Med Hyg. 2007;77:1079-86.

31. Habib M, Mohamed MK, Abdel-Aziz F, Magder LS, Abdel-Hamid M, Gamil F, et al. Hepatitis $C$ virus infection in a community in the Nile Delta: risk factors for seropositivity. Hepatology. 2001;33:248-53.

32. Silva JLA, Coelho MRCD, Souza VSB, Domingues ALC. Soroprevalência da hepatite C em pacientes com esquistossomose. Rev Para Med. 2008;22:27-32.

33. Mohamoud YA, Mumtaz GR, Riome S, Miller D, Abu-Raddad L. The epidemiology of hepatitis C virus in Egypt: a systematic review and data synthesis. BMC Infect Dis. 2013:13:288.

34. Silva JLA, Souza VSB, Vilella TAS, Domingues ALC, Coêlho MRCD. Marcadores sorológicos do VHB e VHC em pacientes com esquistossomose mansônica na forma hepatoesplênica. Arq Gastroenterol. 2011;48:124-30.
35. Edris A, Nour MO, Zedan OO, Mansour AE, Ghandour AA, Omran T. Seroprevalence and risk factors for hepatitis $B$ and $C$ virus infection in Damietta Governorate. Egypt East Mediterr Health J. 2014;20:605-13.

36. Wahib AA, Masoud AA, Halem AA, Haseeb AN, Hassan AR, Darwish MA, et al. Cell mediated immune response in chronic liver diseases: schistosomal, viral and neoplastic. J Egypt Soc Parasitol. 1998;28:929-39.

37. Edwards MJ, Buchatska O, Ashton M, Montoya M, Bickle QD, Borrow P. Reciprocal immunomodulation in a schistosome and hepatotropic virus coinfection model. J Immunol. 2005;175:6275-85.

38. Chen L, Liu WQ, Lei JH, Guan F, Li MJ, Song WJ, et al. Chronic Schistosoma japonicum infection reduces immune response to vaccine against hepatitis B in mice. PLoS One. 2012;7:e51512.

39. Chen SL, Morgan TR. The Natural History of Hepatitis C Virus (HCV) Infection. Int J Med Sci. 2006:3:47-52

40. Elrefaei M, El-Sheikh N, Kamal K, Cao H. HCV-specific CD27-CD28- memory T cells are depleted in hepatitis C virus and Schistosoma mansoni co-infection. Immunology. 2003;110:513-8.

41. Makhlouf LM, Serwah Ael H, Abd El-Hamid Ael D, Hussein EM, Saad RM. INF-gamma, IL-5 and IgE profiles in chronic Schistosomiasis mansoni Egyptian patients with or without hepatitis C infection. J Egypt Soc Parasitol. 2006;36:177-96.

42. Emam EA, Emam M, Shehata AE, Emara M. Impact of Schistosoma mansoni co-infection on serum profile of interferon-gamma, interleukin-4 and interleukin-10 in patients with chronic hepatitis C virus infection. Egypt J Immunol. 2006;13:33-40.

43. El-Awady MK, Youssef SS, Omran MH, Tabll AA, El Garf WT, Salem AM. Soluble egg antigen of Schistosoma Haematobium induces $\mathrm{HCV}$ replication in PBMC from patients with chronic HCV infection. BMC Infect Dis. 2006;6:91.

44. Elsammak MY, Al-Sharkaweey RM, Ragab MS, Amin GM, Kandil MH. In Egyptians, a mutation in the lymphotoxin-alpha gene may increase susceptibility to hepatitis C virus but not that to Schistosomal infection. Ann Trop Med Parasitol. 2008;102:709-16.

45. Abbas OM, Abdel-Rahman MH, Omar NA, Badran HM, Amir EM. Interleukin10 promoter polymorphisms in hepatitis $C$ patients with and without Schistosoma mansoni co-infection. Liver Int. 2009;29:1422-30.

46. Hammad HA, el Fattah MM, Moris M, Madina EH, el Abbasy AA, Soliman AT. Study on some hepatic functions and prevalence of hepatitis B surface antigenaemiain Egyptian children with Schistosomal hepatic fibrosis. J Trop Pediatr. 1990;36:126-7.

47. Al-Freihi HM. Prevalence of hepatitis B surface antigenemia among patients with Schistosoma mansoni. Ann Saudi Med. 1993;13:121-5.

48. Larouze B, Dazza MC, Gaudebout C, Habib M, Elamy M, Cline B. Absence of relationship between Schistosoma mansoni and hepatitis $B$ virus infection in the Qalyub Governate, Egypt. Ann Trop Med Parasitol. 1987;81:373-5.

49. Ye XP, Fu YL, Anderson RM, Nokes DJ. Absence of relationship between Schistosoma japonicum and hepatitis B virus infection in the Dongting lake region, China. Epidemiology and Infection. 1998;121:193-5.

50. Andrade ZA, Berthillon P, Paraná R, Grimaud JA, Trépo C. Schistosomiasis mansoni and viral B hepatitis in woodchucks. J Hepatol. 2001;34:134-9.

51. Osada Y, Kanazawa T. Schistosome: its benefit and harm in patients suffering from concomitant diseases. J Biomed Biotechnol. 2011;2011:264173.

52. McClary H, Koch R, Chisari FV, Guidotti LG. Inhibition of hepatitis B virus replication during Schistosoma mansoni infection in transgenic mice. J Exp Med. 2000;192:289-94.

53. Maria José Conceição and José Rodrigues Coura (2013): Study on Schistosomiasis mansoni and Comorbidity with Hepatitis B and C Virus Infection, Parasitic Diseases - Schistosomiasis, Prof. Rashika El Ridi (Ed.), ISBN: 978-953-51-0942-6, InTech. Available from: http://www.intechopen.com/ books/parasitic-diseases-Schistosomiasis/study-on-Schistosomiasis-mansoniand-comorbidity-with-hepatitis-b-and-c-virus-infection

54. Andrade JR, Silva LD, Guimarães CM, Bassetti-Soares E, Cambraia RD, Couto OF, et al. Chronic hepatitis B and liver schistosomiasis: a deleterious association. Trans R Soc Trop Med Hyg. 2014;108:159-64.

55. Lundy SK, Lukacs NW. Chronic schistosome infection leads to modulation of granuloma formation and systemic immune suppression. Front Immunol. 2013:4:39.

56. Bassily S, Strickland GT, Abdel-Wahab MF, Esmat GE, Narooz S, el-Masry NA, et al. "Efficacy of hepatitis B vaccination in primary school children from a village endemic for Schistosoma mansoni,". J Infect Dis. 1992;166:265-8.

57. Mohamed A, Elsheikh A, Ghandour Z, Al Karawi M. Impact of hepatitis C virus infection on Schistosomal liver disease. Hepatogastroenterology. 1998;45:1492-6. 
58. Gad A, Tanaka E, Orii K, Rokuhara A, Nooman Z, Serwah AH, et al. Relationship between hepatitis $C$ virus infection and Schistosomal liver disease: not simply an additive effect. J Gastroenterol. 2001;36:753-8.

59. Allam WR, Barakat A, Zakaria Z, Galal G, Abdel-Ghafar TS, El-Tabbakh M, et al. Schistosomiasis does not affect the outcome of HCV infection in genotype 4-infected patients. Am J Trop Med Hyg. 2014;90:823-9.

60. Keang H, Odermatt P, Odermatt-Biays S, Cheam S, Degremont A, Hatz C. Liver morbidity due to Schistosoma mekongi in Cambodia after seven rounds of mass drug administration. Trans R Soc Trop Med Hyg. 2007;101:759-65.

61. Huang LH, Qiu YW, Hua HY, Niu XH, Wu PF, Wu HY, et al. The efficacy and safety of entecavir in patients with advanced Schistosomiasis co-infected with hepatitis B virus. Int J Infect Dis. 2013;17:e606-609.

62. Draz HM, Mahmoud SS, Ashour E, Shaker YM, Wu CH, Wu GY. Effects of PEG-interferon-alpha-2A on Schistosoma mansoni infection in mice. J Parasitol. 2010;96:703-8.

63. Derbala MF, Al Kaabi SR, El Dweik NZ, Pasic F, Butt MT, Yakoob R, et al. Treatment of hepatitis $C$ virus genotype 4 with peginterferon alfa-2a: impact of bilharziasis and fibrosis stage. World J Gastroenterol. 2006;12:5692-8.

64. Tian Z, Wang SP, Zeng SH, Liu XQ, Gao DM, Feng QM, et al. Characterization and vaccination of two novel Schistosoma japonicum genes screened from a cercaria CDNA library. Parasitol Res. 2012;110:403-9.

65. Qiu C, Liu S, Hong Y, Fu Z, Wei M, Ai D, et al. Molecular characterization of thyroid hormone receptor beta from Schistosoma japonicum and assessment of its potential as a vaccine candidate antigen against Schistosomiasis in BALB/C mice. Parasit Vectors. 2012;13:5-172.

66. Gray DJ, Li YS, Williams GM, Zhao ZY, Harn DA, Li SM, Ren MY, Feng Z, Guo FY, Guo JG, Zhou J, Dong YL, Li Y, Ross AG, McManus DP. A multicomponent integrated approach for the elimination of Schistosomiasis in the People's Republic of China: design and baseline results of a 4-year cluster-randomised intervention trial. Int J Parasitol. 2014 pii, S0020-751900136-2.

67. Espíndola MS, Frantz FG, Soares LS, Masson AP, Tefé-Silva C, Bitencourt CS, et al. Combined immunization using DNA-Sm14 and DNA-Hsp65 increases CD8+ memory T cells, reduces chronic pathology and decreases egg viability during Schistosoma mansoni infection. BMC Infect Dis. 2014;14:263.

68. Zhang W, Ahmad G, Le L, Rojo JU, Karmakar S, Tillery KA, et al. Longevity of Sm-p80-specific antibody responses following vaccination with Sm-p80 vaccine in mice and baboons and transplacental transfer of Sm-p80-specific antibodies in a baboon. Parasitol Res. 2014;113:2239-50.

69. Moyle PM, Toth I. Self-Adjuvanting lipopeptide vaccines. Curr Med Chem. 2008;15:506-16.

70. Garcia A, Fernandez S, Toro F, De Sanctis JB. An Overview Of Hepatitis C Vaccines. Recent Pat Inflamm Allergy Drug Discov. 2014;8:85-91.

71. Baldo V, Bonanni P, Castro M, Gabutti G, Franco E, Marchetti F, et al. Combined hexavalent diphtheria-tetanus-acellular pertussis-hepatitis B-inactivated poliovirus-Haemophilus influenzae type $b$ vaccine; Infanrix ${ }^{\text {TM }}$ hexa: Twelve years of experience in Italy. Hum Vaccin Immunother. 2014:10:129-37.

72. Vesikari T, Forstén A, Desole MG, Ferrera G, Caubet M, Mesaros N, et al. A combined Haemophilus influenzae type B Neisseria meningitidis serogroup $C$ tetanus toxoid conjugate vaccine is immunogenic and well-tolerated when coadministered with diphtheria, tetanus, acellular pertussis hepatitis B-inactivated poliovirus at 3,5 and 11 months of age: results of an open, randomized, controlled study. Pediatr Infect Dis J. 2013;32:521-9.

\section{Submit your next manuscript to BioMed Central and take full advantage of:}

- Convenient online submission

- Thorough peer review

- No space constraints or color figure charges

- Immediate publication on acceptance

- Inclusion in PubMed, CAS, Scopus and Google Scholar

- Research which is freely available for redistribution

Submit your manuscript at www.biomedcentral.com/submit 